\title{
Anti-acetylcholine receptor antibody titres in the sera of myasthenia patients treated with plasma exchange combined with immunosuppressive therapy
}

\author{
BARBARA CARTER, ROGER HARRISON, GEORGE G LUNT, PETER O BEHAN, \\ AND JOHN A SIMPSON
}

From the Department of Bivchemistry, University of Bath, Bath, and Department of Neurology, Institute of Neurological Sciences, Glasgow.

SUMMARY Anti-acetylcholine receptor antibody titres have been monitored in the sera of 19 myasthenic patients treated with plasma exchange combined with a three month period of immunosuppressive therapy. In general the post-exchange titres stabilised at below pre-exchange levels for prolonged periods which were associated with clinical improvement. In seven instances recurrence of symptoms occurred and in six of these cases relapse was shown to be associated with a rise in anti-acetylcholine receptor antibody titre.

Myasthenia gravis is now generally accepted to be an autoimmune disease in which circulating antibodies specific for the acetylcholine receptor (AChR) play an important role. ${ }^{1}$ Plasma exchange has been successfully used in the treatment of Goodpasture's syndrome, ${ }^{2}$ an autoimmune disease in which antibodies are formed against glomerular and pulmonary basement membranes ${ }^{3}$ and reports have appeared of its application to myasthenic patients. $^{4-7}$ These papers describe the results of plasma-exchange used in conjunction with immunosuppressive therapy in the treatment of limited numbers (maximum seven) of myasthenic patients, and serial assays of circulating antiAChR antibodies over periods of up to 12 months are reported. ${ }^{7}$ Nineteen myasthenic patients have now been treated by plasma-exchange in combination with a three month period of immunosuppression and the details of their clinical condition throughout an 18 month follow-up period have been reported. ${ }^{8}$ The anti-AChR antibody titres of these patients were assayed over the same period and these results are discussed in the present paper.

\section{Patients and methods}

Patients Nineteen patients with undisputed myasthenia gravis were studied. All patients had

Address for reprint requests: $\mathrm{Dr} R$ Harrison, Department of Biochemistry, University of Bath, Claverton Down, Bath BA2 7AY. Accepted 7 February 1980 the disease confirmed by a classical clinical history, demonstrable fatiguable weakness, a positive response to edrophonium hydrochloride and a decrementing response to repetitive supramaximal nerve stimulation. There were 12 females and seven males, whose ages ranged from 26 to 75 with a mean of 51 years. Seventeen patients had the generalised form of the disease, whilst two had only the eye muscles clinically affected. Myasthenia had been present from 2-29 years with a mean duration of 10 years. Sixteen patients had had a thymectomy previously.

All patients were on anticholinesterase therapy. Five were also on steroids (30-60 mg prednisolone per day) prior to plasma exchange, and three of these five patients had received, in the preceding six months, a three-month course of azathioprine ( $150 \mathrm{mg}$ daily), in addition to their steroids, without showing any clinical improvement.

Plasma exchange Patients had from 16-32 litres of plasma exchanged on continuous flow cell separators over a period of two to three weeks. Replacement fluid in all cases was plasma protein fraction.

Immunosuppression At the end of the first week of plasma exchange, that is, after the third exchange, each patient was placed on prednisolone (100 mg daily) and azathioprine (150 mg daily). The azathioprine dose was maintained for three months but the steroids were gradually reduced over this period. Patients undergoing a single course of plasma exchange were not treated with 
immunosuppressive drugs beyond this point, whereas those undergoing a second course of plasma exchange were treated with drugs over a further three month period exactly as described above.

Clinical assessment Patients were graded before treatment and four months later. An objective assessment of the severity of myasthenia was obtained using: 1 the maximum time that outstretched arms could be held horizontally; 2 measurements of lung vital capacity (table).

${ }^{125} I$-Iodination of $\alpha$-bungarotoxin $\alpha$-Bungarotoxin from Bungarus multicinctus was purchased from Boehringer, Mannheim as a lyophilised powder (1 $\mathrm{mg})$ which was reconstituted in distilled water $(2 \mathrm{ml})$ and stored at $-20^{\circ} \mathrm{C}$ prior to use. The stock solution $(20 \mu 1)$ was added to ${ }^{125}$ Iodine $(100 \mathrm{mCi} / \mathrm{ml}$, The Radiochemical Centre, Amersham) $(10 \mu \mathrm{l}), 0.5 \% \mathrm{w} / \mathrm{v}$ Chloramine $\mathrm{T}$ in $0.01 \mathrm{M}$-potassium phosphate buffer, $\mathrm{pH} 7.5$, $(10 \mu 1)$ and $0.05 \mathrm{M}$-potassium phosphate buffer, pH 7.5 $(10 \mu 1)$. The mixture was stirred for $1 \mathrm{~min}$ after which were added $0.016 \mathrm{w} / \mathrm{v}$ sodium metabisulphite in $0.01 \mathrm{M}$-potassium phosphate buffer, $\mathrm{pH} 7.5(0.75 \mathrm{ml})$ and $1 \%{ }^{\mathrm{w}} / \mathrm{v} \mathrm{KI}$ in $0.01 \mathrm{M}$ potassium phosphate-buffer, $\mathrm{pH} 7.5,(0.2 \mathrm{ml})$ giving a final volume of $1 \mathrm{ml}$. The solution was added to a column $(27 \mathrm{~cm} \times 1 \mathrm{~cm})$ of Sephadex G-25, (previously allowed to swell overnight in $0.05 \mathrm{M}$ potassium phosphate buffer, $\mathrm{pH} 7 \cdot 5$, and equilibrated in $0.01 \mathrm{M}$ potassium phosphate buffer, pH $7 \cdot 5$, containing $1 \%$ bovine serum albumin) and eluted with $0.01 \mathrm{M}$-potassium phosphate buffer, pH $7 \cdot 5$, containing $1 \%$ bovine serum albumin. Fractions $(1 \mathrm{ml})$ were collected and samples $(5 \mu \mathrm{l})$ counted on a $\gamma$-counter. The most active fractions of the first, protein-containing peak of radioactivity were combined and the specific activity of the pooled fractions (the "stock" solution) was calculated assuming total recovery of protein and relating this to acidprecipitable counts. The "stock" solution was diluted 100 times in assay buffer $(0.01 \mathrm{M}$-potas-

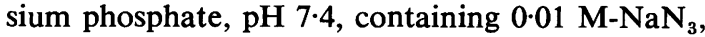
$0.1 \% \mathrm{w} / \mathrm{v}$ bovine serum albumin and $1 \% \mathrm{v} / \mathrm{v}$ Triton X-1C0) to give the "working" solution used in determination of AChR activity and in the radioimmunoassay.

Preparation of AChR from human skeletal muscle Human skeletal muscle was obtained from amputated legs at the time of operation and either used immediately or stored at $-20^{\circ} \mathrm{C}$. The chopped muscle was homogenised $(1 \mathrm{~min})$ in 4 volumes of phosphate-buffered saline containing $0.01 \mathrm{M}$-potassium phosphate, $0.1 \mathrm{M}-\mathrm{NaCl}$ and $0.01 \mathrm{M}-\mathrm{NaN}_{3}$, and then centrifuged at $20,000 \mathrm{~g}$ for $1 \mathrm{~h}$ at $+4^{\circ} \mathrm{C}$. The pellet was resuspended in 2 volumes of phosphate-buffered saline, as above but with the addition of $2 \% \mathrm{v} / \mathrm{v}$ Triton X-100, stirred for $16 \mathrm{~h}$ at $+4^{\circ} \mathrm{C}$ and centrifuged at $20,000 \mathrm{~g}$ for $1 \mathrm{~h}$ at $+4^{\circ} \mathrm{C}$. The resulting supernatant was filtered through glass wool to remove lipid particles and stored at $+4^{\circ} \mathrm{C}$.

The concentration of $\mathrm{AChR}$ in the receptor preparation was determined by the binding of ${ }^{12}$ 'I- $\alpha$-bungarctoxin. The receptor extract

Table Clinical data for myasthenic patients

\begin{tabular}{|c|c|c|c|c|c|c|c|c|c|c|}
\hline \multirow{2}{*}{$\begin{array}{l}\text { Case } \\
\text { no }\end{array}$} & \multirow{2}{*}{$\begin{array}{l}\text { Sex, } \\
\text { age }\end{array}$} & \multirow{2}{*}{$\begin{array}{l}\text { Duration } \\
\text { of disease } \\
(y r)\end{array}$} & \multirow{2}{*}{$\begin{array}{l}\text { Years } \\
\text { since } \\
\text { thymectomy }\end{array}$} & \multicolumn{2}{|c|}{ Before plasma exchange } & \multicolumn{2}{|l|}{ Drugs } & \multicolumn{3}{|c|}{ Four months afier plasma exchange } \\
\hline & & & & $\begin{array}{l}\text { Vital } \\
\text { capacity } \\
\text { (litres) }\end{array}$ & $\begin{array}{l}\text { Duration of } \\
\text { outstretched } \\
\text { arms } \\
\text { (seconds) }\end{array}$ & $\begin{array}{l}\text { pyr. } \\
\text { mg/day }\end{array}$ & $\begin{array}{l}\text { ster. } \\
\text { mg/day }\end{array}$ & $\begin{array}{l}\text { Vital } \\
\text { capacity } \\
\text { (litres) }\end{array}$ & $\begin{array}{l}\text { Duration of } \\
\text { outstretched } \\
\text { arms } \\
(\text { seconds })\end{array}$ & $\begin{array}{l}\text { Drugs } \\
\text { pyr. } \\
\text { mg/dxy }\end{array}$ \\
\hline $1 *$ & M.61 & 18 & 18 & respirator & $\mathbf{0}$ & 1080 & 40 & $3 \cdot 2$ & 56 & 120 \\
\hline 2 & M.51 & 6 & 1 & $2 \cdot 5$ & 12 & 480 & & $3 \cdot 5$ & 48 & \\
\hline 3 & F.30 & 3 & 2 & respirator & $\mathbf{0}$ & 360 & 40 & $3 \cdot 0$ & 110 & \\
\hline 4 & F.26 & 4 & $\overline{3}$ & 3.0 & 28 & 720 & & $3 \cdot 5$ & 58 & \\
\hline 5 & F.43 & 8 & 2 & $2 \cdot 8$ & 16 & 360 & & $3 \cdot 5$ & 150 & \\
\hline 6 & F.64 & 29 & - & $2 \cdot 8$ & 18 & 420 & & $3 \cdot 4$ & 140 & 240 \\
\hline 7 & F.66 & 4 & 3 & $3 \cdot 0$ & 21 & 780 & & $3 \cdot 5$ & 48 & \\
\hline 8 & F.46 & 20 & 7 & $2 \cdot 6$ & 26 & 120 & & $3 \cdot 3$ & 73 & \\
\hline $9^{*}$ & F.68 & 10 & 4 & $2 \cdot 4$ & 82 & 720 & & $3 \cdot 0$ & 91 & 180 \\
\hline 10 & M.46 & 20 & 18 & $2 \cdot 5$ & 5 & 1020 & & $3 \cdot 5$ & 101 & 120 \\
\hline $11 \dagger$ & M.46 & 5 & 2 & $3 \cdot 5$ & not impaired & 240 & & $3 \cdot 5$ & not impaired & \\
\hline 12 & M.66 & 3 & 1 & respirator & 2 & 720 & & $3 \cdot 4$ & 116 & \\
\hline 13 & F.56 & 2 & - & $3 \cdot 2$ & 43 & 720 & & $3 \cdot 5$ & 117 & 300 \\
\hline $14^{*}$ & M.36 & 10 & 7 & $3 \cdot 0$ & 38 & 1200 & $40 \ddagger$ & $3 \cdot 5$ & 110 & 360 \\
\hline $15 t$ & F.52 & 20 & 18 & $3 \cdot 5$ & not impaired & 1020 & & 3.5 & not impaired & 720 \\
\hline 16 & F.47 & 16 & 10 & $2 \cdot 2$ & 27 & 480 & & $3 \cdot 5$ & 88 & \\
\hline 17 & M.62 & 5 & 3 & respirator & 6 & 720 & $60 \ddagger$ & 3.4 & 92 & \\
\hline 18 & F.28 & 3 & 3 & $2 \cdot 6$ & 1 & 600 & $25 \ddagger$ & $3 \cdot 5$ & 180 & \\
\hline 19 & F.75 & 5 & - & $2 \cdot 1$ & 88 & 480 & & $3 \cdot 5$ & 173 & 240 \\
\hline
\end{tabular}

* thymoma; focular myasthenia only; łplus $150 \mathrm{mg}$ azathioprine daily. pyr. = pyridostigmins; ster. = pre 1 nisolone. 
$\left(\begin{array}{ll}100 & \mu l\end{array}\right)$ was mixed with ${ }^{125} \mathrm{I}-\alpha$-bungarotoxin solution (see above) $(50 \mu \mathrm{l})$, saturated $\left(\mathrm{NH}_{4}\right)_{2} \mathrm{SO}_{4}$ solution $(104 \mu \mathrm{l})$ and assay buffer, $(100 \mu \mathrm{l})$, and the mixture was incubated for $16 \mathrm{~h}$ at $+4^{\circ} \mathrm{C}$. The resulting precipitate was collected on glass fibre filters (Whatman Ltd., Maidstone, U.K.) washed with $30 \% \mathrm{w} / \mathrm{v}$ aqueous $\left(\mathrm{NH}_{4}\right)_{2} \mathrm{SO}_{4}$ solution and counted in a $\gamma$-counter. The assay was repeated as above except that the assay buffer additionally contained $0.1 \mathrm{mM}$-curare and the counts so cblained were subtraoted to give specific binding. Anti-AChR antibody assay Anti-AChR antibodies in the sera of myasthenic patients were assayed by a modification of the assay described by Lindstrom. ${ }^{9}$

AChR extract $\left(0.9 \mathrm{ml}, 1.5-2.0 \times 10^{-10} \mathrm{M}\right)$ was mixed with assay buffer $\left(\begin{array}{lll}100 & \mu l\end{array}\right)$ and ${ }^{125} \mathrm{I}-\alpha-$ bungarotoxin "working" solution and incubated for $6-8 \mathrm{~h}$ at $+4^{\circ} \mathrm{C}$. Test serum $(5 \mu \mathrm{l})$ was added to the mixture which was then allowed to stand at $+4^{\circ} \mathrm{C}$ for $16 \mathrm{~h}$ before goat anti(human IgG) antiserum was added to precipitate the ${ }^{125} I-\alpha$ bungarotoxin-AChR-antibody complex. The supernatant was removed after centrifugation $(3000 \times g, 10 \mathrm{~min})$ and the pellet was washed with $0.01 \mathrm{M}$-potassium phosphate buffer, $\mathrm{pH} 7 \cdot 0$, containing $0.85 \%{ }^{\mathrm{w}} / \mathrm{v} \mathrm{NaCl}$ and $0.01 \mathrm{M}-\mathrm{NaN}_{3}$ and counted in a $\gamma$-counter.

Correction for non-specifically-bound ${ }^{125} \mathrm{I}-\alpha$ bungarotoxin was made by carrying out parallel assays in which the AChR extract was mixed with $0.1 \mathrm{mM}$ curare prior to addition of ${ }^{125} \mathrm{I}-\alpha$ bungarotoxin. The counts so obtained were subtracted from those in the assay described above, giving specific binding which was expressed as moles ${ }^{125} \mathrm{I}-\alpha$-bungarotoxin binding sites per litre of serum.

In general, series of serum samples from an individual patient were assayed using a single AChR extract. However comparability between extracts was always checked by repeat assays on standard samples of myasthenic sera.

Serum samples taken in Glasgow were immediately frozen at $-20^{\circ} \mathrm{C}$ and were maintained frozen until their assay, which was performed at Bath.

\section{Results}

Nineteen myasthenic patients (table) were plasma-exchanged over a period of two to three weeks, after the first week of which an immunosuppressive regimen was initiated and subsequently maintained for three months (see the Patients and Methods section). Anti-AChR antibody titres in the sera of these patients were periodically assayed for up to 18 months (mean 12 months) following plasma exchange, during which time five patients (cases $3,6,7,9$ ) were treated with a second course of plasma exchange and immunosuppression. The clinical states of these patients have been fully described in a previous paper. ${ }^{8}$

During the periods of observation all 19 patients showed anti-AChR antibody titres (fig 1) that were significantly elevated $\left(3-284 \times 10^{-10} \mathrm{M}\right.$ $\alpha$-bungarotoxin sites) relative to those of normal controls $\left(0.6 \times 10^{-10} \mathrm{M}\right.$ sites, SEM, $\left.0 \cdot 1, \mathrm{n}=20\right)$.

The titre of each patient was measured during the course of plasma-exchange and a typical pattern of values is shown in fig 2 . Not surprisingly each exchange resulted in a sharp fall in antiAChR antibody titre which rose before the next exchange, but which after three exchanges generally remained well below the initial value. After the third exchange the average titre (of 22 courses of plasma-exchange) was $22 \%$ of the pre-exchange level while after the complete series of exchanges (average 5.8 exchanges per course) it was $16 \%$.

Following a series of plasma exchanges, the anti-AChR antibody titres remained below preexchange levels for the total period of postexchange observation (between 6 and 18 months) in 13 out of the 18 patients followed. One patient (case 1) died 4 months after completion of exchange. ${ }^{8}$ In these cases the general pattern was that of a sharp rise in titre during the first month after a series of exchanges followed by a gradual fall and stabilisation of titres over the ensuing months (fig 1). Of the five patients (cases 3, 5, 11, 17, 19) who showed elevated post-exchange antiAChR antibody titres (that is above pre-exchange levels), three (cases $3,17,19)$ suffered a recurrence of myasthenic symptoms coincident with their elevated titres (fig $1(b)(e)$ ). In addition four further patients (cases $6,7,9,14$ ) underwent relapses. In three of these (cases $6,7,14$ ) the recurrence of symptoms was also assnciated with a peak of anti-AChR-antibody titre although in these cases pre-exchange levels were not surpassed. The remaining patient (case 9) suffered two relapses (fig $1(b)$ ) which were not shown to coincide with elevated titres.

It is noteworthy that of the three patients with thymoma, all had relatively high preexchange anti-AChR antibody titres and two (cases 9 and 14) suffered subsequent relapses. The third (case 1) died of total marrow failure and septicaemia. ${ }^{8}$ The numbers are clearly too small, however, to attach particular significance to this at the present stage. 

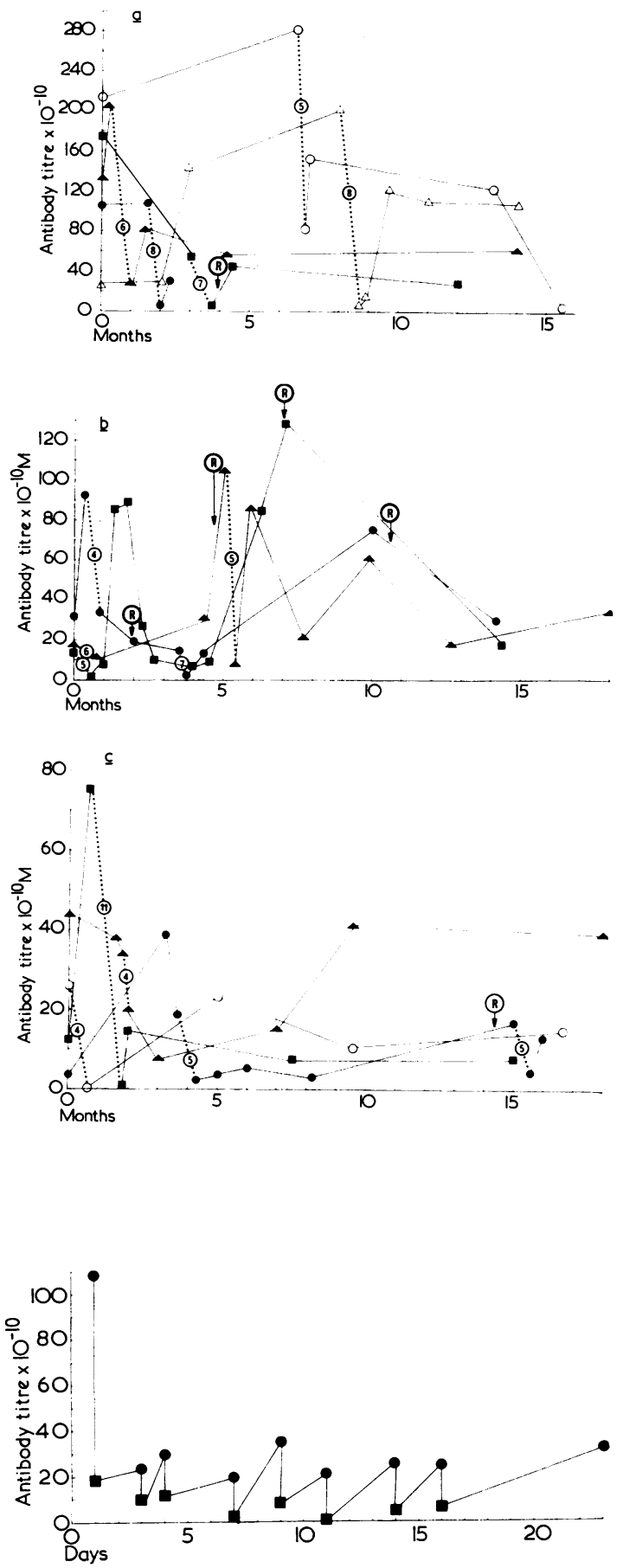

Fig 2 A typical pattern of anti-AChR antibody titres observed over a single course of plasma-exchanges (Case I): 0 , pre-exchange; 1, post-exchange.
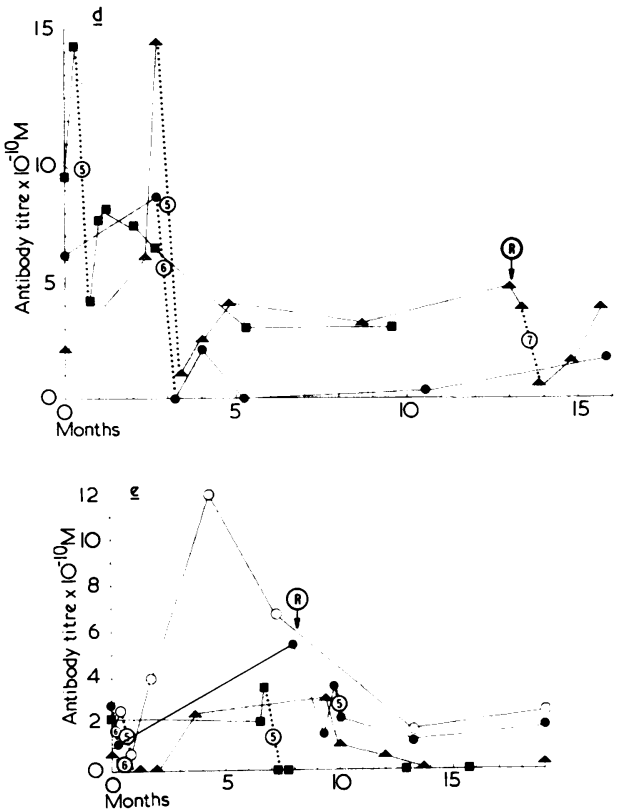

Fig 1 Anti-AChR antibody titres of myasthenic patients monitored over periods of time that include at least one plasma-exchange.

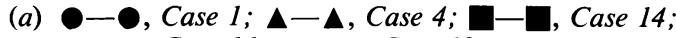
$\bigcirc-\bigcirc$, Case 16; $\triangle-\triangle$, Case 18 .

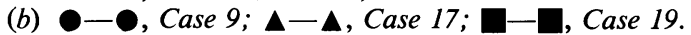

(c) - - Case 7; $\mathbf{\Delta}-\mathbf{\Lambda}$, Case 12; $\square-$, Case 13; 0 - 0 , Case 15.

(d) -- Case 2; $\Delta-\Delta$, Case 6; $\square-$, Case 10.

(e) - Case 3; $\mathbf{\Delta - \Lambda}$, Case 5; O-O, Case 11.

Dotted lines thus: . . 5 . . indicate a series of plasma-exchanges; the number of individual exchanges being shown in the circle. $\circledR^{\circledR}$ indicates recurrence of myasthenic symptoms.

\section{Discussion}

Our observation of elevated anti-AChR antibody titres in all the myasthenic patients described in this paper is consistent with previous figures of around $90 \%^{10} 11$ obtained from large samples of myasthenics in a range of clinical states. Although correlation of antibody titre with severity of disease is generally poor, ${ }^{11}{ }^{12}$ it is true that the clinical state of a given patient is often reflected in his anti-AChR titre over a period of time $\mathrm{e}^{11}$ and the patients chosen for plasmaexchange contain many whose clinical condition, in spite of conventional treatment, has continued to deteriorate. The probability of elevated titres in these patients might accordingly be expected 
to be somewhat higher than that of a random sample.

The lack of good correlation between antiAChR antibody titre and clinical state across a range of patients is well illustrated by the present data. Thus the pre-exchange titres range from 0.8 to $284 \times 10^{-10} \mathrm{M} \alpha$-bungarotoxin-binding sites of which one of the highest $\left(205 \times 10^{-10}\right.$ $M$ sites) was shown by a patient (case 4) with relatively good physical performance (table) whereas a pre-exchange titre of only $2.8 \times 10^{-10} \mathrm{M}$ $\alpha$-bungarotoxin binding sites was obtained from one (case 3 ) of the four patients confined to a respirator.

The pattern of anti-AChR antibody titres shown in fig 2 is typical of that obtained during the course of each series of plasma exchanges in the present study and is similar to others reported previously. ${ }^{6}{ }^{12}$

The combination of plasma-exchange with a three month course of immunosuppression in the present study led to a marked clinical improvement ${ }^{8}$ which was maintained for up to 18 months (mean 12.5 months) in 11 out of 19 patients. A further four patients had a second plasmaexchange following recurrence of symptoms (after $4,8,10$ and 10 months respectively). After this second exchange their clinical state improved and was maintained for $13,9, \frac{1}{2}$ and 2 months respectively. ${ }^{8}$ In 13 out of these 15 recovered patients their sustained clinical improvement was associated with anti-AChR antibody titres that apparently remained below the pre-exchange levels throughout the post-exchange period. Conversely, of the seven patients who suffered recurrence of myasthenic symptoms (cases 3, 6, $7,9,14,17,19$ ), six (cases $3,6,7,14,17,19$ ) showed a worsening of their clinical condition that was accompanied by an elevation in antiAChR antibody titre, although in only three of these cases (cases 3, 17, 19) was the preexchange level surpassed. Our results clearly support earlier conclusions, based on smaller numbers of patients treated with extended immunosuppression, ${ }^{6} 713$ that an inverse relationship generally exists between clinical state and anti-AChR antibody titres after plasma-exchange, although we have observed both elevation of titre without obvious relapse (cases 5, 11) and relapse without observed rise in titre (case 9; in this case, however, a transient rise in titre could well have been missed).

The fact that anti-AChR antibody titres generally correspond to clinical condition when serially assayed in a single patient and yet not when compared across a range of patients, sug- gests either that individuals have widely different threshold values for antibody-initiated impairment of function or that anti-AChR antibodies as presently assayed are not the primary agents in the aetiology of myasthenia gravis. They could merely reflect variations in a more basic pathogenic factor which could, for instance, simply be a particular sub-population of AChR antibodies. Heterogeneity of anti-AChR antibodies in myasthenic sera has been demonstrated by several combinations of differential assay methods (Mittag et $a l^{14-18}$ ), but no sub-population whose titres show close correlation with disease state has yet been identified.

Newsom-Davis et al $^{7}{ }^{7}$ have compared the long term reductions in anti-AChR antibody titre brought about in 7 patients receiving plasmaexchange, in combination with extended periods of immunosuppression, with the reductions produced in six patients treated by immunosuppression alone. They found that the percentage decrease in AChR antibody titre was not significantly different in the two groups of treated patients and concluded that plasmaexchange is of use only in the short term control of severe myasthenic symptoms. Our presently described use of plasma exchange ccmbined with a three month period of immunosuppression has led to dramatic clinical improvement in most of the 19 patients so treated ${ }^{8}$ and the general reduction of anti-AChR antibody titres over a long period is comparable with that obtained by Newsom-Davis and his colleagues. The evidence ${ }^{8}$ that a more extensive series of plasma exchanges can lead to greater chances of long term improvement is of interest in view of the anti-AChR antibody titre profiles observed during the course of a single series of plasma exchanges. As plasma-exchanges beyond the third appear to lead to relatively little further reduction in anti-AChR antibody titre, it is possible that the reduction in titre per se is of less long term relevance than the repeated stimulation of the immune system in the presence of antimetabolites. Thus it may be, as suggested by Dau et $a l,{ }^{6}$ that azathioprine mediates a semi-selective cytotoxic action on specific lymphocytes proliferating in response to removal of anti-AChR antibodies from the circulation. The continued monitoring of the patients treated in the present study may well serve to clarify this issue. Meanwhile the demonstrated efficacy of plasmaexchange combined with a limited period of immunosuppression in bringing about sustained clinical improvement together with depressed anti-AChR antibody levels serve to recommend 
its use as a viable treatment of severe myasthenia gravis.

We are grateful to the Muscular Dystrophy Group of Great Britain for support.

\section{References}

1 Simpson JA. Myasthenia Gravis: A personal view of pathogenesis and mechanism, Part 2. Muscle and Nerve 1978; 1:151-6.

2 Lockwood CM, Rees AJ, Pearson TA, Evans DJ, Peters DK, Wilson CB. Immunosuppression and plasma-exchange in the treatment of Goodpasture's syndrome. Lancet 1976; i:711-5.

3 Paul JJ, Dixon FJ. Characterisation of Immunoglobulin $G$ anti-glomerular basement membrane antibodies eluted from kidneys of patients with Glomerulonephritis. J Immunol 1971; 107:678-84.

4 Pinching AJ, Peters DK, Newsom-Davis J. Remission of myasthenia gravis following plasmaexchange. Lancet 1976; ii:1373-6.

5 Finn R, Coates PM. Plasma-exchange in myasthenia gravis. Lancet 1977; i:190-1.

6 Dau PC, Lindstrom JM, Cassel CK, Denys EH, Shev EE, Spitler LE. Plasmapheresis and immunosuppressive drug therapy in myasthenia gravis. $N$ Engl J Med 1977; 297:1134-40.

7 Newsom-Davis J, Vincent A, Wilson SG, Ward CD. Long term effects of repeated plasma exchange in myasthenia gravis. Lancet 1979; i:464-8.

8 Behan PO, Shakir RA, Simpson JA, Burnett AK, Haase G, Allan TL. Plasma exchange combined with immunosuppressive therapy in the treatment of myasthenia gravis. Lancet 1979; ii:438-47.

9 Lindstrom J. An assay for antibodies to human acetylcholine receptor in serum from patients with myasthenia gravis. Clinical Immunology and Immunopathology 1977; 7:36-43.

10 Lindstrom J, Seybold ME, Lennon VA,
Whittingham S, Duane DD. Antibody to acetylcholine receptor in myasthenia gravis. Neurology 1976; 26:1054-9.

11 Lefvert AK, Bergström K, Matell G, Osterman PO, Pirskanen R. Determination of acetylcholine receptor antibody in myasthenia gravis: clinical usefulness and pathogenic implications. J Neurol Neurosurg Psychiatry 1978; 41:394-403.

12 Barkas T, Harrison R, Lunt GG, Stephenson FA, Behan PO, Simpson JA. Acetylcholine receptor antibody titres in myasthenia gravis. In: Behan PO, Clifford Rose A, eds. Progress in Neurological Research with particular reference to motor neurone disease. Tunbridge Wells: Pitman Medical Press, 1979: 169-73.

13 Newsom-Davis J, Pinching AJ, Vincent A, Wilson SG. Function of circulating antibody to acetylcholine receptor in myasthenia gravis: Investigation by plasma-exchange. Neurology 1978; 28:266-72.

14 Mittag TW, Tormay A, Marsa T. Heterogeneity of acetylcholine receptors in denervated muscle: interactions of receptors with immunoglobulin from patients with myasthenia gravis. Mol Pharmacol 1978; 14:60-8.

15 Savage-Marengo T, Harrison R, Lunt GG, Behan PO. Rat or human acetylcholine receptor antigen for investigation of myasthenia gravis? Lancet 1979; i:442.

16 Savage-Marengo T, Harrison R, Lunt GG, Behan PO. Patient-specific anti-acetylcholine receptor antibody patterns in myasthenia gravis. J Neurol Neurosurg Psychiatry 1980; in the press.

17 Vincent A, Newsom-Davis J. Bungarotoxin and anti-acetylcholine receptor antibody binding to the human acetylcholine receptor. Adv Cytopharmacol 1979; 3:269-78.

18 Weinberg CB, Hall ZW. Antibodies from patients with myasthenia gravis recognise determinants unique to extrajunctional acetylcholine receptors. Proc Nat Acad Sci USA 1979; 76:504-8. 